\title{
THE SOURCES OF AEROSOL ELEMENTAL CARBON AT ALLEGHENY MOUNTAIN
}

\author{
G. J. KeELER \\ University of Michigan, Ann Arbor, MI 48109-2029, U.S.A. \\ S. M. Japar, W. W. Brachaczek, R. A. Gorse, Jr, J. M. Norbeck and W. R. Pierson* \\ Research Staff, Ford Motor Company, Dearborn, MI 48121, U.S.A.
}

(First received 16 August 1988 and in final form 9 May 1990)

\begin{abstract}
Aerosol elemental carbon measurements were taken at two rural sites in southwestern Pennsylvania during August 1983. Carbon, though a small part of the aerosol mass at both sites, was a leading constituent of the aerosol on an atom basis. Time-weighted average concentrations at Allegheny Mountain and Laurel Hill were 1.2 and $1.4 \mu \mathrm{g} \mathrm{m}^{-3}$, respectively. Absolute Principal Component Analysis followed by multiple regression and Chemical Mass Balance techniques were utilized to apportion the measured elemental carbon to its sources. Motor vehicles were estimated to be the largest source of elemental carbon at the two sites, contributing $41-68 \%$ and $34-56 \%$ at Allegheny Mountain and Laurel Hill, respectively.
\end{abstract}

Key word index: Atmospheric aerosol, elemental carbon, lead, source apportionment, chemical mass balance, principal component analysis.

\section{INTRODUCTION}

While elemental carbon (EC), or black carbon, is a ubiquitous component of atmospheric aerosols, it has only recently become the focus of scientific studies. Because of its role in atmospheric light absorption and other environmental issues, it is important to determine the sources of EC in the atmosphere.

As a product of combustion, EC is found not only in urban air (Pierson and Russell, 1979; Groblicki et al., 1981; Wolff et al., 1982, 1983; Cass et al., 1984; Gray et al., 1984; Pratsinis et al., 1984), but also in rural airsheds (Ferman et al., 1981; Japar et al., 1986) and in such remote areas as over tropical oceans (Goldberg, 1963; Andreae et al., 1984; Clarke et al., 1984b) and in the Arctic (Rahn and McCaffrey, 1980; Clarke et al., 1984a). There have been a number of studies aimed at identifying the sources of EC in atmospheric aerosols, but they have been carried out primarily in urban areas (Groblicki et al., 1981; Wolff et al., 1982; Wolff and Korsog, 1985; Pratsinis et al., 1988). In two studies in which source identification was attempted, motor vehicles were found to account for 47 and $93 \%$ of the measured aerosol EC (Wolff et al., 1985; Pratsinis et al., 1988).

Given these results and the relative lack of data from rural areas, we included aerosol EC analysis (Japar et al., 1986) in an extensive field experiment in

* Present address: Energy and Environmental Engineering Center, Desert Research Institute, Reno, NV 89506, U.S.A. rural Pennsylvania in 1983 (Pierson et al., 1987, 1989; Vossler et al., 1989). This paper details our investigation of the source apportionment of the aerosol EC measured in that study.

\section{EXPERIMENTAL}

\section{Sample collection}

Samples were collected during 5-28 August 1983 on abandoned radio towers atop Allegheny Mountain (elevation $838 \mathrm{~m}$ ) and Laurel Hill (elevation $850 \mathrm{~m}$ ) in southwestern Pennsylvania (Fig. 1). The sites are $35.5 \mathrm{~km}$ apart. Both sites are heavily forested and experience no local vehicle traffic. The samples were taken 4-5 $\mathrm{m}$ above the top of the forest canopies (17-21 $\mathrm{m}$ above the ground).

For the carbon analysis, pre-fired $\left(600^{\circ} \mathrm{C}\right.$, air/overnight) Pallflex QAO quartz-fiber filters $\left(8^{\prime \prime} \times 10^{\prime \prime}\right)$ were employed for sample collection using high volume samplers operated at flow rates of $1.1-1.4 \mathrm{~m}^{3} \mathrm{~min}^{-1}$ using a cyclone with an inlet having a $50 \%$ cut-point at $5.5 \mu \mathrm{m}$. Samples were generally collected twice a day, from about $10 \mathrm{a} . \mathrm{m}$. (EDT) to 5 p.m., and from 9 p.m. to 7 a.m. the next morning. After each run the front filters were removed and placed in styrofoam trays, covered with aluminium foil and stored at room temperature before analysis.

\section{Carbon analysis}

The analytical procedures have been described in detail (Japar et al., 1986). Sections of the loaded filters, with appropriate blanks, were analyzed by a thermal-optical method (Huntzicker et al., 1982; Johnson et al., 1981). The stated analytical precisions were $0.81,0.47$ and $0.96 \mu \mathrm{g} \mathrm{cm}^{-2}$ for organic, elemental, and total carbon, respectively. The overall accuracy for total carbon was better than $10 \%$.

Subsequent to these analyses, a field comparison of analytical methods for elemental (and organic) carbon was 

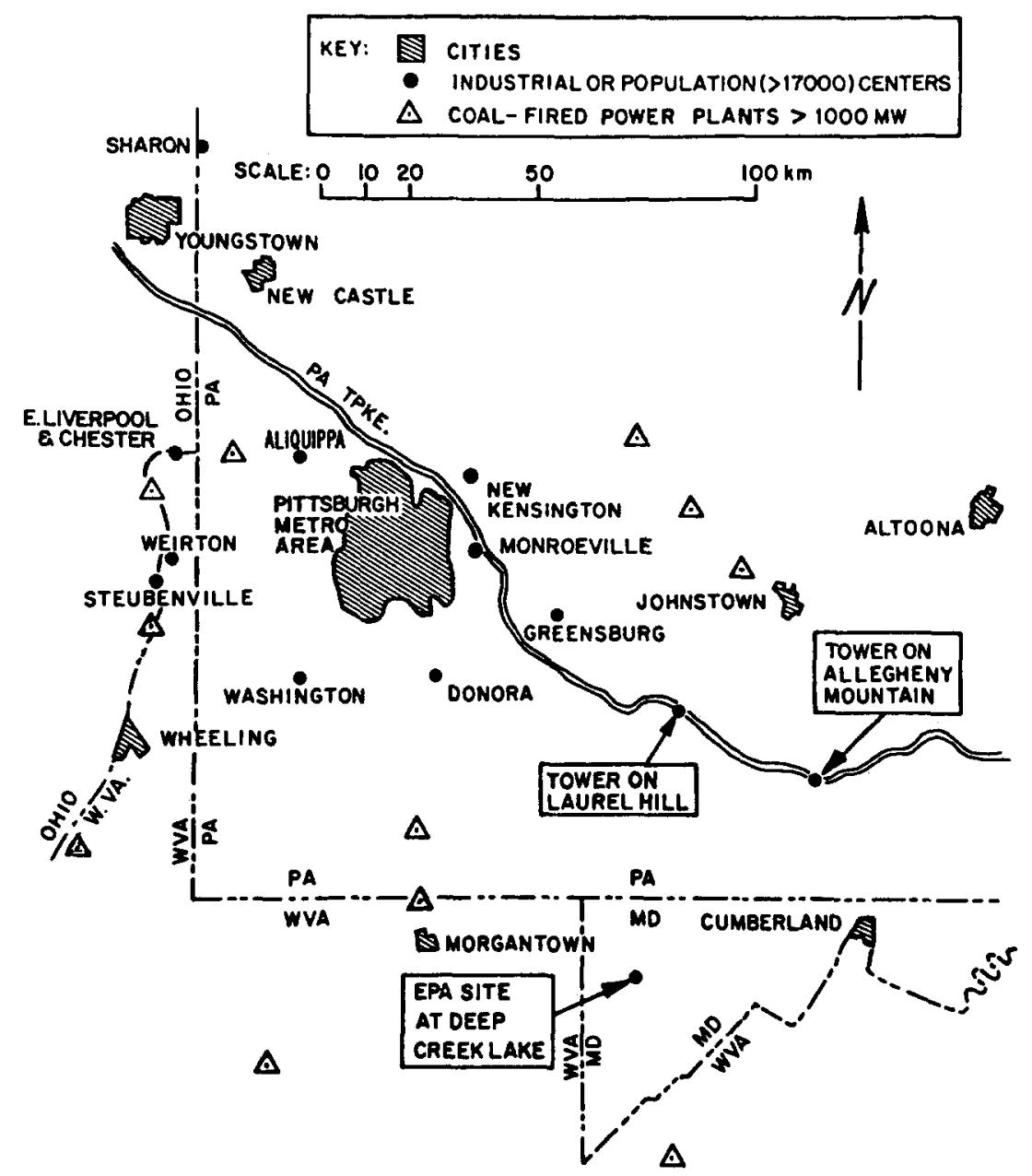

Fig. 1. Map of southwestern Pennsylvania, showing the locations of the sampling sites, urban areas and industrial centers, and coal-burning power plants.

carried out in Glendora, California, in September 1986. The results of that study (Countess, 1987) indicate the possibility that the elemental carbon concentrations reported for the 1983 experiment may be as much as $25 \%$ higher than EC measured by other methods. In the thermal-optical method (here, using reflectance as in Huntzicker et al., 1982, or Johnson et al., 1981), an optical offset is applied to account for the EC produced by charring of organic carbon in the early part of the sample analysis procedure. The results obtained by one (though not both) of the two sourceapportionment procedures employed below could be significantly affected, as will be described. The potential problem is much less in the 1983 Allegheny/Laurel samples than in the 1986 Glendora samples, however, since the uncorrected elemental fraction of the total carbon is much higher in the Allegheny/Laurel case $(\sim 0.4)$ than in the Glendora case.

\section{Other analyses}

Trace element concentrations, which must be known in order to perform the carbon source apportionment, were determined for 47 elements on dichotomous sampler filters at each site using $X$-ray fluorescence (XRF) and instrumental neutron activation analysis (INAA) for both fine $(<2.5 \mu \mathrm{m})$ and coarse $(2.5-10 \mu \mathrm{m})$ particles. Details of the sampling and analyses of the other pertinent atmospheric constituents appear in our discussion of the atmospheric acidity at Allegheny Mountain (Pierson et al., 1989).

\section{SOURCE APPORTIONMENT METHODS}

One of the major goals of the 1983 AlleghenyLaurel experiment was to relate the measured aerosol elemental carbon, and other species, to their sources (Keeler, 1987). It soon became clear that a single modeling approach would not help us achieve that goal, owing primarily to the large and complex source regions just upwind of the measurement sites. Therefore, several receptor modeling approaches have been utilized in this study and the results of each will be discussed and compared in this paper as they relate to the apportionment of elemental carbon. A recent book on receptor modeling (Hopke, 1985), as well as a number of journal review articles, other books, and conference proceedings (Cooper and Watson, 1980; Gordon, 1980, 1988; Henry et al., 1984; Hopke and Dattner, 1982; Macias and Hopke, 1981; Pace, 1986; Stevens and Pace, 1984; Watson, 1981, 1989), can be consulted for more details on the source apportionment techniques discussed below. More details on the application of these techniques to the present data set are given in Keeler (1987). 
Absolute Principal Component Analysis (APCA) was first utilized to apportion the aerosol elemental carbon measured at the two sites. This technique involves performing Principal Component Analysis (PCA) followed by multiple linear regression on the absolute principal component scores (Thurston, 1983). Other applications of PCA applied to air pollution and meteorological data can be found in the literature (Henry and Hidy, 1979, 1982; Thurston and Spengler, 1985a,b; Wolff et al., 1984). In using PCA, one assumes that the measured concentration of each element on each filter is the sum of the elemental contributions from each of a finite number of source components. The calculated correlation between the principal components and the elemental species is used to identify the source types associated with each component. It was found that identification of the components was facilitated by transforming the components using a varimax rotation (Harmon, 1976). Mass contributions can then be estimated for each of the identified principal components by regressing the mass on the absolute scores of the principal components (Thurston, 1983; Thurston and Spengler, 1985a). This procedure was also performed to apportion the elemental carbon and other individual species of interest.

The Chemical Mass Balance (CMB) method, also referred to as the Chemical Element Balance (CEB) method, was also utilized in this study to apportion the elemental carbon. The method was first utilized by Miller et al. (1972) and Friedlander (1973), and has been applied to eastern U.S. regional-scale source apportionment by Rahn and Lowenthal (1985). A discussion of the CMB method is given in recent review articles (Gordon, 1986, 1988; Javitz et al., 1988; Watson et al., 1984). The CMB model is currently recommended by the EPA for $\mathrm{PM}_{10}$ source assessment (Pace and Watson, 1987).

\section{RESULTS}

\section{Chemical composition of the rural atmosphere}

Time-weighted average concentrations of the airborne species important to understanding the atmospheric chemistry at the two sites are presented in Table 1. These results are discussed in detail elsewhere (Pierson et al., 1987, 1989). In summary, the ambient acidity is evident in the $\mathrm{HNO}_{3}(\mathrm{~g})$ and in the larger amounts of aerosol $\mathrm{H}^{+}$, the lack of $\mathrm{NH}_{3}(\mathrm{~g})$, and the potential acid represented by the $\mathrm{SO}_{2}$. The lack of $\mathrm{NH}_{3}(\mathrm{~g})$ is consistent with the pronounced aerosol acidity, as is the lack of aerosol $\mathrm{NO}_{3}^{-}$(most of the inorganic nitrate is present as $\mathrm{HNO}_{3}(\mathrm{~g})$ ) or of aerosol $\mathrm{Cl}$. Carbon, though a small part of the aerosol mass at both sites, was a very substantial portion of the aerosol chemical composition on an atom basis. The aerosol mass not recorded in Table 1 was probably water; at the $50 \%$ r.h. of the weighing room, an aqueous $\mathrm{H}_{2} \mathrm{SO}_{4}$ solution in vapor pressure equilibrium with the air is $43.1 \% \mathrm{H}_{2} \mathrm{SO}_{4}$ by mass (Stokes and Robinson, 1948). The vapor pressure lowering by $\left(\mathrm{NH}_{4}\right)_{2} \mathrm{SO}_{4}$ or $\mathrm{NH}_{4} \mathrm{HSO}_{4}$ is only slightly less than that by $\mathrm{H}_{2} \mathrm{SO}_{4}$. The water estimated by this means would account for $71 \%$ of the unrecorded mass at Allegheny and $96 \%$ at Laurel.

\section{Principal Component Analysis results}

Particulate fine fraction analysis-Allegheny Mountain. Varimax rotated PCA was applied to the fine

Table 1. Time-averaged atmospheric concentrations during the 1983 Allegheny Mountain-Laurel Hill Experiment

\begin{tabular}{|c|c|c|c|c|}
\hline Parameter & $\begin{array}{r}\text { Allegheny } \\
\left(\text { nmole } \mathrm{m}^{-3}\right)\end{array}$ & $\begin{array}{l}\text { Mountain } \\
\qquad\left(\mu \mathrm{g} \mathrm{m}^{-3}\right)\end{array}$ & $\begin{array}{c}\text { Laure } \\
\text { (nmole } \mathrm{m}^{-3} \text { ) }\end{array}$ & $\begin{array}{l}\text { Hill } \\
\left(\mu \mathrm{g} \mathrm{m}^{-3}\right)\end{array}$ \\
\hline $\mathrm{SO}_{2}$ & 409 & 26 & 490 & 31 \\
\hline $\mathrm{O}_{3}$ & 2178 & 105 & - & - \\
\hline $\mathrm{NO}$ & 11 & 0.3 & $66^{*}$ & $2.0^{*}$ \\
\hline $\mathrm{NO}_{2}+\mathrm{PAN}$ & 220 & & $316^{*}$ & \\
\hline PAN & $46+$ & $6 \dagger$ & 一 & - \\
\hline $\mathrm{HNO}_{3}$ & 71 & 4.5 & 85 & 5.3 \\
\hline Aerosol mass & & $64 \pm \$$ & & $59 \neq 11$ \\
\hline $\mathrm{H}^{+}$ & 193 & 0.2 & 216 & 0.2 \\
\hline $\mathrm{NH}_{4}^{+}$ & 173 & 3.1 & 171 & 3.1 \\
\hline $\mathrm{NO}_{3}^{-}$ & 8 & 0.5 & 10 & 0.6 \\
\hline $\mathrm{SO}_{4}^{2-}$ & 195 & 18.7 & 206 & 19.8 \\
\hline Other S & 150 & 0.59 & 219 & 0.79 \\
\hline $\mathrm{Cl}$ & 3 & 0.1 & 2 & 0.08 \\
\hline C elemental & 102 & 1.2 & $11 \overline{6}$ & 1.4 \\
\hline C organic & 169 & 2.0 & 188 & 2.3 \\
\hline
\end{tabular}

* Laurel $\mathrm{NO}_{x}$ data are questionable.

+ PAN GC/ECD data available only for last half of experiment.

$\ddagger$ Mass in weighing room at $20^{\circ} \mathrm{C}$ and $50 \%$ r.h.

$\$ 76 \%$ of mass was fine (MMD $<2.5 \mu \mathrm{m}$ ).

$\| 78 \%$ of mass was fine (MMD $<2.5 \mu \mathrm{m}$ ).

ๆ Total particulate $\mathrm{S}$ (by combustion) minus $\mathrm{SO}_{4}^{2-}$. 
fraction $(<2.5 \mu \mathrm{m})$ particle data collected at the Allegheny Mountain site, and the results are shown in Table 2 . In addition to the elemental data, $\mathrm{SO}_{4}^{2-}, \mathrm{H}^{+}$, $\mathrm{NH}_{4}^{+}$, and $\mathrm{EC}$ data were also utilized in the fine fraction analysis.

The six principal components shown in Table 2 account for $86 \%$ of the total variance in the data with $27 \%$ accounted for by the first component. This first component (PC1) evidently is the crustal or soil component since it has high loadings for $\mathrm{Si}, \mathrm{K}, \mathrm{Ca}, \mathrm{Ti}$ and $\mathrm{Fe}$. Moderate loadings for $\mathrm{Zn}$ and Se suggest that PC1 includes another source impact in addition to the soil source. Evidence for an additional local source impact is inferred from the significant correlation of $\mathrm{SO}_{2}(\mathrm{~g})$ with this component (PC1) and the finding that both $\mathrm{PCl}$ and $\mathrm{SO}_{2}(\mathrm{~g})$ were highly correlated with the soil component calculated from the coarse fraction ( $>2.5 \mu \mathrm{m}$ ) particle data.

The second component (PC2) appears to represent coal combustion products, with high loadings for $\mathrm{SO}_{4}^{2-}, \mathrm{H}^{+}$, and $\mathrm{Se}$ and moderate loadings for $\mathrm{NH}_{4}^{+}$, $\mathrm{Al}, \mathrm{Mn}, \mathrm{Zn}$ and As. Selenium has been used to identify coal source impacts in past studies (Hopke et al., 1976; Spengler and Thurston, 1984; Stevens et al., 1984; Wolff and Korsog, 1985) because coal combustion is the primary anthropogenic source of atmospheric Se (NAS, 1980).

PC2 is also highly loaded with species which could represent emissions from motor vehicles, i.e. $\mathrm{Br}, \mathrm{EC}$ and $\mathrm{Pb}$. While $\mathrm{Br}$ and $\mathrm{Pb}$ have been measured in coalfired power plant emissions (Sheffield and Gordon, 1986), these elements are not highly enriched compared to species such as $\mathrm{Se}$ in these emissions. Source sampling has shown coal-fired power plants to be an insignificant source of $\mathrm{EC}$ in the atmosphere relative to diesel engine emissions, wood burning, and other sources (Olmez et al., 1988). Analysis of coal fly-ash revealed that $\mathrm{EC}$ constituted only $0.3 \%$ of the total mass of the ash (Fisher et al., 1979). Wolff et al. (1981) determined that coal combustion sources contributed at most $1 \%$ of the measured EC in Denver. A difficulty with the foregoing analysis is that the $\mathrm{Pb}$ variance on the putative coal/auto component $\mathrm{PC} 2$ is not large (0.46, Table 2) and, moreover, is not comparable to the much more reasonable value for $\mathrm{Br}(0.83)$. The only way that we could explain this would be to suppose another $\mathrm{Pb}$ source (which we have no evidence for) at Allegheny.

The smearing of multiple source types onto a single component was also found in analysis of data taken at three sites in the Ohio River Valley and at a site in the Shenandoah Valley (Tuncel, 1986). In fact, the components identified by Tuncel as being motor vehicle factors were always found to have moderate to high loadings of elements not usually associated with motor vehicles, such as $\mathrm{Sb}, \mathrm{Zn}$, As, and even Se. It appears that PCA may be unable to separate certain source types in a complex source area. It is also possible that other factors, such as meteorology, may force a correlation between motor vehicle tracers and tracers of other strong source types influencing the measurement sites. For example, Sexton et al. (1985) suggested that low night-time wind speeds enhanced the buildup of local emissions at their Waterbury, VT, site and caused high loadings of motor vehicle tracers $\mathrm{Br}$ and $\mathrm{Pb}$ ) and wood burning tracers ( $\mathrm{K}$ and $\mathrm{Ca}$ ) on the same component. Meteorological factors, such as wind direction and ambient humidity (Keeler et al., 1988), may

Table 2. Factor loadings from varimax-rotated principal component analysis of Allegheny Mountain fine fraction data

\begin{tabular}{|c|c|c|c|c|c|c|}
\hline & $\mathrm{PCl}$ & PC2 & PC3 & PC4 & $\mathrm{PC} 5$ & PC6 \\
\hline Al & 0.73 & 0.35 & -0.19 & -0.05 & 0.24 & 0.34 \\
\hline $\mathbf{S i}$ & 0.87 & 0.31 & -0.07 & 0.05 & 0.09 & 0.17 \\
\hline $\mathbf{K}$ & 0.92 & 0.16 & 0.14 & 0.10 & 0.06 & 0.09 \\
\hline $\mathrm{Ca}$ & 0.92 & 0.18 & -0.02 & -0.08 & -0.12 & 0.09 \\
\hline $\mathrm{Ti}$ & 0.80 & 0.00 & 0.11 & -0.17 & 0.31 & -0.10 \\
\hline V & -0.31 & 0.11 & 0.14 & 0.82 & -0.05 & -0.10 \\
\hline $\mathbf{M n}$ & 0.37 & 0.38 & 0.07 & -0.03 & 0.75 & 0.17 \\
\hline $\mathrm{Fe}$ & 0.82 & 0.14 & 0.12 & 0.25 & 0.38 & 0.11 \\
\hline Co & 0.29 & 0.03 & -0.05 & 0.85 & 0.21 & 0.13 \\
\hline $\mathrm{Cu}$ & -0.06 & 0.06 & 0.87 & 0.06 & 0.03 & -0.08 \\
\hline $\mathrm{Zn}$ & 0.41 & 0.33 & 0.47 & 0.26 & 0.38 & 0.31 \\
\hline As & 0.10 & 0.28 & 0.75 & -0.06 & 0.07 & 0.41 \\
\hline $\mathrm{Se}$ & 0.39 & 0.73 & 0.11 & -0.16 & 0.37 & 0.01 \\
\hline $\mathrm{Br}$ & 0.20 & 0.83 & 0.25 & 0.09 & -0.25 & 0.15 \\
\hline $\mathbf{P b}$ & 0.17 & 0.46 & 0.49 & 0.38 & 0.44 & 0.18 \\
\hline $\mathrm{SO}_{4}^{2-}$ & 0.19 & 0.79 & 0.09 & 0.07 & 0.25 & 0.48 \\
\hline $\mathrm{H}^{+}$ & 0.11 & 0.88 & 0.01 & 0.07 & 0.26 & 0.21 \\
\hline $\mathrm{NH}_{4}^{+}$ & 0.25 & 0.44 & 0.24 & 0.17 & 0.15 & 0.74 \\
\hline $\mathrm{EC}$ & 0.22 & 0.85 & 0.14 & 0.13 & 0.11 & -0.00 \\
\hline Eigenvalue & 5.2 & 4.4 & 2.0 . & 1.8 & 1.6 & 1.4 \\
\hline $\begin{array}{l}\text { Cumulative } \% \text { of } \\
\text { variance }\end{array}$ & 27 & 51 & 61 & 71 & 79 & 86 \\
\hline
\end{tabular}


also have contributed to the apparent smearing of the coal combustion and motor vehicle sources onto the same factor in this study.

The third component (PC3) appears to represent an incineration source, with high loadings for $\mathrm{Cu}$ and $\mathrm{As}$ and moderate loadings for $\mathrm{Zn}$ and $\mathrm{Pb}$. $\mathrm{Ag}$, In and $\mathrm{Sb}$ were all found to be significantly correlated to this component, and these elements are said to be good tracers for municipal incinerators (Sheffield and Gordon, 1986).

The fourth component (PC4) represents fuel oil combustion with high loadings for $\mathrm{V}$ and $\mathrm{Co}$, and a moderate loading for $\mathrm{Pb}$. $\mathrm{Ni}$, which was removed from the PCA analysis because of a large number of zero values determined from the XRF analysis, was also correlated with this component. The loading of $\mathrm{Co}$ on this component was at first surprising, as Co is not generally considered a highly enriched species in oil combustion emissions (Sheffield and Gordon, 1986). However, it was recently reported that oil combustion is a major source of Co in Philadelphia (Dzubay et al., 1988). The high PC4 component scores at Allegheny and Laurel were generally associated with flow around the back side of a high pressure area which resulted in a looping flow pattern from the southeast and northeast, depending upon the location of the high pressure center relative to the sites. The largest $V$ concentrations at both sites were observed when air flow was from the southeast, specifically from the direction of Cumberland, Maryland.

A high loading for $\mathrm{Mn}$ and moderate loadings for $\mathrm{Ti}, \mathrm{Fe}, \mathrm{Zn}, \mathrm{Se}$ and $\mathrm{Pb}$ suggest that the fifth component (PC5) represents an iron-steel source. Iron and steel production is one of the most important industrial source types in western Pennsylvania and in the
Midwest (Tuncel, 1986; Wolff et al., 1984). The last component (PC6) most likely represents a smelter/industrial source with moderate loadings for $\mathrm{Al}, \mathrm{Zn}, \mathrm{As}$, and $\mathrm{SO}_{4}^{2-}$, and a high loading for $\mathrm{NH}_{4}^{+}$. We can only presume that the high loading for $\mathrm{NH}_{4}^{+}$results from atmospheric reaction of $\mathrm{NH}_{3}(\mathrm{~g})$ with the PC6 emissions, since it is hard to imagine $\mathrm{NH}_{4}^{+}$emitted from such a source. This factor explained the least amount of variance in the data set. Although the retention of PC6 is marginal since its eigenvalue is only 1.4 (Table 2 ), discarding it does slightly affect the other components; hence its retention.

Particulate fine fraction analysis-Laurel Hill. The result of applying varimax rotated PCA on the Laurel Hill fine fraction particle data is given in Table 3 . The six-component solution is seen to account for $88 \%$ of the total variance. The first component (PC1) is the soil component, as is often the case in PCA of elemental species. High loadings are again seen for $\mathrm{Al}, \mathrm{Si}$, $\mathrm{K}, \mathrm{Ca}$ and Ti. Moderate loadings are also seen for fine $\mathrm{Mn}, \mathrm{Fe}, \mathrm{Cu}, \mathrm{Zn}$ and $\mathrm{Se}$, which, except for $\mathrm{Fe}$, are most likely pollution-derived elements. This component may represent resuspended dust or local source impacts in addition to the soil impacts. This was also observed at Allegheny with $\mathrm{SO}_{2}$ being significantly correlated with the soil component.

The coal combustion component (PC2) was the second most important component, explaining approximately $25 \%$ of the total variance. $\mathrm{PC} 2$ is found to have high loadings of Se, $\mathrm{SO}_{4}^{2-}, \mathrm{H}^{+}$and $\mathrm{EC}$, and moderate loadings of $\mathrm{Mn}, \mathrm{Zn}, \mathrm{As}, \mathrm{Br}$ and $\mathrm{NH}_{4}^{+}, \mathrm{Pb}$ is weakly loaded on this component, and both $\mathrm{Pb}$ and $\mathrm{Br}$ are seen to have smaller loadings on the Laurel coal combustion component than on the Allegheny coal combustion component. The EC loading at Laurel is

Table 3. Factor loadings from varimax-rotated principal component analysis of Laurel Hill fine fraction data

\begin{tabular}{lrrrrrr}
\hline & PC1 & PC2 & PC3 & PC4 & PC5 & PC6 \\
\hline $\mathrm{Al}$ & 0.83 & 0.35 & 0.03 & 0.04 & 0.19 & 0.13 \\
$\mathrm{Si}$ & 0.79 & 0.39 & -0.08 & 0.06 & 0.29 & 0.13 \\
$\mathrm{~K}$ & 0.79 & 0.01 & 0.25 & -0.04 & 0.28 & 0.17 \\
$\mathrm{Ca}$ & 0.88 & 0.14 & 0.10 & -0.10 & 0.17 & 0.16 \\
$\mathrm{Ti}$ & 0.70 & 0.14 & 0.24 & -0.21 & -0.13 & -0.06 \\
$\mathrm{~V}$ & 0.01 & 0.01 & -0.10 & 0.91 & -0.02 & -0.17 \\
$\mathrm{Mn}$ & 0.51 & 0.41 & 0.35 & -0.14 & 0.11 & 0.13 \\
$\mathrm{Fe}$ & 0.32 & 0.23 & 0.08 & 0.09 & 0.06 & 0.84 \\
$\mathrm{Co}$ & -0.01 & -0.01 & 0.23 & 0.82 & -0.06 & 0.38 \\
$\mathrm{Cu}$ & 0.32 & -0.01 & 0.14 & -0.09 & 0.82 & 0.02 \\
$\mathrm{Zn}$ & 0.50 & 0.37 & 0.61 & 0.03 & 0.35 & 0.03 \\
$\mathrm{As}$ & -0.00 & 0.35 & 0.59 & -0.20 & 0.50 & 0.33 \\
$\mathrm{Se}$ & 0.49 & 0.67 & 0.20 & -0.17 & -0.02 & 0.18 \\
$\mathrm{Br}$ & 0.32 & 0.39 & 0.66 & 0.29 & 0.08 & 0.12 \\
$\mathrm{~Pb}$ & 0.29 & 0.28 & 0.83 & 0.12 & 0.25 & 0.02 \\
$\mathrm{SO}_{4}^{2-}$ & 0.24 & 0.96 & 0.14 & 0.07 & 0.25 & 0.01 \\
$\mathrm{H}^{+}$ & 0.10 & 0.96 & 0.16 & -0.02 & -0.03 & 0.11 \\
$\mathrm{NH}_{4}^{+}$ & 0.22 & 0.58 & 0.34 & 0.54 & 0.15 & -0.02 \\
$\mathrm{EC}_{\text {Eigenvalue }}$ & 0.20 & 0.86 & 0.15 & 0.10 & 0.03 & 0.16 \\
$\mathrm{Cumulative}^{+}$of & 4.8 & 4.7 & 2.5 & 2.0 & 1.6 & 1.2 \\
variance & 25 & 50 & 63 & 74 & 82 & 88 \\
\hline
\end{tabular}


seen to be very close to that at Allegheny. While the coal-related elemental loadings were similar for Allegheny and Laurel, the motor vehicle loadings were not. This indicates a difference in motor vehicle impacts at the two sites. This difference is also apparent in the continuous measurements of $\mathrm{NO}, \mathrm{NO}_{2}, \mathrm{O}_{3}$, and condensation nuclei count (CNC) at the sites (Pierson et al., 1989).

The third component (PC3) appears to represent a smelter/industrial component. PC3 is highly loaded with $\mathrm{Pb}$, and moderately loaded with $\mathrm{Mn}, \mathrm{Zn}, \mathrm{As}, \mathrm{Br}$ and $\mathrm{NH}_{4}^{+}$. The loadings of $\mathrm{Pb}$ and $\mathrm{Br}$ suggest a motor vehicle influence but the loading of $\mathrm{EC}$ was fairly small on this component.

The interpretation of the fourth component (PC4) is straightforward since it has high loadings for $\mathrm{V}$ and Co. This component represents oil combustion. The high loading of Co was also observed in the Allegheny fine fraction analysis, which suggests that the association of $\mathrm{V}$ and $\mathrm{Co}$ is a real source influence. The CMB analysis of the fine fraction data also indicated that a large fraction of the observed fine Co was from oil combustion sources.

The fifth component (PC5) is seen to be highly loaded with $\mathrm{Cu}$ and moderately loaded with $\mathrm{Zn}, \mathrm{As}$, and $\mathrm{NH}_{4}^{+}$. This component appears to represent a copper/incineration component. The sixth component (PC6) was found to have a high loading for Fe and moderate loadings for Co and As. This component appears to represent iron-steel sources influencing the site. The loading of $\mathrm{Fe}$ on this component is much higher than that found on the soil component. This was not observed in the Allegheny fine PCA. The timeweighted-average coarse $\mathrm{Fe}$ concentrations were virtually identical at the two sites, but the time-weightedaverage fine $\mathrm{Fe}$ concentration at Laurel was approx- imately $25 \%$ higher than at Allegheny. This may indicate that the PCA result reflects a real difference in source impacts between the two sites.

A difficulty with the foregoing analysis is that the component with the largest variance for $\mathrm{Br}$ and $\mathrm{Pb}$ (PC3, variances 0.66 and 0.83 , respectively; see Table 3 ) is not the one that is supposed to contain the automotive component (PC2). Moreover, EC, which below will be ascribed largely to automotive sources, is loaded mostly on a component different from that on which $\mathrm{Br}$ and $\mathrm{Pb}$ are mostly loaded. We cannot offer an explanation.

PCA source apportionment of elemental carbon. The contributions from each source component to the observed concentration of EC at Allegheny and Laurel are given in Tables 4 and 5. Dashes in these tables indicate statistically insignificant $(\alpha \geqslant 0.1)$ regression coefficients for that species and component. The sources which have no entry for EC were found to have insignificant regression coefficients for that source.

The largest contributor to the EC concentration measured at Allegheny was $\mathrm{PC} 2$, the coal combustion/motor vehicle component. Approximately $50 \%$ of the observed EC was accounted for by this component. However, since this is a dual-source component, the question is how much of the EC can be attributed to each of the two sources on this component. As was discussed above, coal combustion is not expected to be a major source of $\mathrm{EC} \mathrm{(or} \mathrm{Pb}$ and $\mathrm{Br}$ ) in the atmosphere. One can make an estimate of the EC contribution from coal-fired power plants by utilizing the knowledge (based on source profile measurements) that between $0.15 \%$ and $0.89 \%$ of the fine particle mass emitted from coal-fired power plants is EC (Fisher et al., 1979; Olmez et al., 1988). Normalizing

Table 4. PCA-derived fine-particle and $\mathrm{HNO}_{3}$ concentrations associated with each source component at Allegheny Mountain

\begin{tabular}{llccccccc}
\hline & Units & $\begin{array}{c}\text { PC1 } \\
\text { Soil }\end{array}$ & $\begin{array}{c}\text { PC2 } \\
\text { Coal }\end{array}$ & $\begin{array}{c}\text { PC3 } \\
\text { Incin. }\end{array}$ & $\begin{array}{c}\text { PC4 } \\
\text { Oil }\end{array}$ & $\begin{array}{c}\text { PC5 } \\
\text { Steel }\end{array}$ & $\begin{array}{c}\text { PC6 } \\
\text { Smelter }\end{array}$ & Observed \\
\hline $\mathrm{Br}$ & $\mathrm{ng} \mathrm{m}^{-3}$ & 0.70 & 2.21 & 0.72 & - & 0.13 & 0.03 & 4.2 \\
$\mathrm{~Pb}$ & $\mathrm{ng} \mathrm{m}^{-3}$ & 4.08 & 7.76 & 8.29 & 4.23 & - & 0.26 & 34.5 \\
$\mathrm{HNO}_{3}(\mathrm{~g})$ & neq m$^{-3}$ & 31 & 34 & - & - & - & 2.0 & 77 \\
$\mathrm{NO}_{3}^{-}$ & neq m$^{-3}$ & - & 2 & - & 1.0 & 1.0 & - & 7.3 \\
$\mathrm{EC}$ & $\mu \mathrm{g} \mathrm{m}^{-3}$ & 0.21 & 0.60 & 0.10 & 0.06 & - & 0.01 & 1.2 \\
\hline
\end{tabular}

Table 5. PCA-derived fine-particle and $\mathrm{HNO}_{3}$ concentrations associated with each source component at Laurel Hill

\begin{tabular}{llccccccc}
\hline & Units & $\begin{array}{c}\text { PC1 } \\
\text { Soil }\end{array}$ & $\begin{array}{c}\text { PC2 } \\
\text { Coal }\end{array}$ & $\begin{array}{c}\text { PC3 } \\
\text { Smelter }\end{array}$ & $\begin{array}{c}\text { PC4 } \\
\text { Oil }\end{array}$ & $\begin{array}{c}\text { PC5 } \\
\text { Incin. }\end{array}$ & $\begin{array}{c}\text { PC6 } \\
\text { Steel }\end{array}$ & Observed \\
\hline $\mathrm{Br}$ & $\mathrm{ng} \mathrm{m}^{-3}$ & 0.79 & 0.51 & 1.65 & 0.45 & - & - & 4.41 \\
$\mathrm{~Pb}$ & $\mathrm{ng} \mathrm{m}^{-3}$ & 6.35 & 3.08 & 20.2 & 1.84 & - & - & 41.1 \\
$\mathrm{HNO}_{3}(\mathrm{~g})$ & neq m$^{-3}$ & 21 & 31 & - & - & - & - & 85 \\
$\mathrm{NO}_{3}^{-}$ & neq m$^{-3}$ & - & 2 & 3 & - & 1.0 & - & 10 \\
$\mathrm{EC}$ & $\mu \mathrm{g} \mathrm{m}^{-3}$ & 0.20 & 0.56 & 0.15 & 0.06 & 0.02 & 0.09 & 1.36 \\
\hline
\end{tabular}


this estimate to the Al content of coal emissions results in a EC/Al ratio of 0.021 . Multiplying this ratio by the fine $\mathrm{Al}$ concentration estimated for the coal-fired power plant component gives an estimate of $0.32 \mathrm{ng} \mathrm{m}^{-3}$ of $\mathrm{EC}$, which is less than $0.15 \%$ of the total EC attributed to the coal combustion/motor vehicle component. Even if we assume that all of the measured fine $\mathrm{Al}$ was from coal-fired power plants then the EC contribution from coal would be only $0.60 \%$ of the observed EC at Allegheny. It thus appears that coal-fired power plants can be considered a negligible contributor to the observed EC at Allegheny Mountain. The Deep Creek Lake results reported by Gordon et al. (1989) support this argument as they found negligible EC on their regional sulfate component and most of the explained EC on the motor vehicle component. Their success in splitting the motor vehicle and transported coal combustion sources in the Deep Creek analysis is probably due to the larger number of samples (103) which should provide a more robust solution.

An indicator of motor vehicle source influence is the $\mathrm{Br} / \mathrm{Pb}$ ratio. Values in the range $0.25-0.35$ are common in areas influenced by motor vehicle emissions (Harrison and Sturges, 1983; Pierson and Brachaczek, 1983). In this work, the mean $\mathrm{Br} / \mathrm{Pb}$ ratio calculated for this component (PC2) was 0.29. This ratio is also similar to the $\mathrm{Br} / \mathrm{Pb}$ ratio of about 0.34 found for Pasadena (Los Angeles Basin) by Hammerle and Pierson (1975), the value of 0.26 reported by Thurston (1983) for Watertown, MA, and the value of 0.30 estimated by Wolff and Korsog (1985) for Detroit. It thus appears likely that component PC2 includes motor vehicle emissions in addition to the coal combustion source influence.

If all of the EC estimates for PC2 is assigned to motor vehicles, then $0.60 \mu \mathrm{g} \mathrm{m}^{-3}$ or $50 \%$ of the total EC measured was due to motor vehicles. Approximately $18 \%$ of the EC was attributed to the soil/local source impacts component. This component also appears to have a motor vehicle contribution with significant amounts of $\mathrm{Pb}, \mathrm{Br}$ and $\mathrm{EC}$ associated with it. The mean $\mathrm{Br} / \mathrm{Pb}$ ratio calculated for this component was 0.17 . Although this was lower than the automotive range suggested above, the relatively high volatility of $\mathrm{Br}$ may be responsible. An upper limit for the motor vehicle contribution of $\mathrm{EC}$ can be calculated by assuming that all of the EC on the first two components was of motor vehicle origin. This results in an estimate of $<0.81 \mu \mathrm{g} \mathrm{m}^{-3}$ or $<67.5 \%$ of the measured EC at Allegheny Mountain. The oil combustion source (PC4) contributed $6 \%$ of the measured $\mathrm{EC}$ and the incineration component (PC3) contributed $8 \%$.

The coal/motor vehicle component accounted for about $0.56 \mu \mathrm{g} \mathrm{m}^{-3}$ or $41 \%$ of the EC measured at Laurel Hill, on the average. The soil/local source component accounted for about $15 \%$ of the EC, similar to the soil/local source contribution found at Allegheny. Adding the EC contributions of the first two source components at Laurel gives an upper limit of $0.76 \mu \mathrm{g} \mathrm{m}^{-3}$ or $56 \%$ for the EC attributable to motor vehicles. The oil combustion source (PC4) contributed $5 \%$ of the measured EC at Laurel and the incineration component (PC5) contributed $<2 \%$. The smelter/industrial source component (PC3) accounted for about $10 \%$ of the measured EC and the iron-steel source (PC6) contributed about 7\%. Approximately $20 \%$ of the EC measured at Laurel could not be attributed to any source type. A potential source of some of the unexplained EC could be aircraft, as the Pittsburgh airport is located about $80 \mathrm{~km}$ northwest of the Laurel site. Wolff et al. (1981) estimated that about $6 \%$ of the EC measured in Denver was from aircraft emissions. Brush fires were observed near Allegheny Mountain during several sampling runs, though it is not clear that the fires had any effect on the levels of EC measured.

PCA source apportionment of other atmospheric species. The regression of individual fine fraction aerosol species on the absolute principal component scores, calculated from the rotated PCA, results in estimates of source contribution to each species from each identified source type. Estimated study-average species concentrations associated with each of the components are also given in Tables 4 and 5. Not all of the measured species are given in the tables, but only those species that are important to understanding the sources of the EC.

\section{Chemical Mass Balance results}

Source profiles. Source components were obtained from the source-composition library developed at the University of Maryland (Sheffield and Gordon, 1986) and were documented by Tuncel (1986). The 11 source components utilized in this CMB analysis were coal-fired power plants (Coal), oil-fired power plants (Oil), refuse incineration (Incin), soil, marine (MAR), refineries (Refin), motor vehicles (MV), iron-steel plants (Steel), copper plant (CU), cement plants (Cem), and a transported coal combustion related component (Tran). These 11 source types were selected after examination of the most important source types in the Ohio River Valley/Midwest Region. The sources were also selected to avoid the serious problem of multicollinearities in the mathematical fitting procedure, discussed by Thurston and Laird (1984). All of the source components utilized were from the Maryland library except the motor vehicle and soil components, which were obtained from Pierson and Brachaczek (1983) and were adjusted to reflect the $\mathrm{Pb}$ content of gasoline at the time of the 1983 experiment. The normalized source profiles for each of the 11 sources used in this study are documented in Keeler (1987). The number of elements used in the fitting procedure varied from 12 to 16 out of a total of 40 , and resulted in solutions which were insensitive to the number of fitted elements used. The average fraction of each species in each source relative to the observed concentration of that species was determined. Only 
those elements that are crucial to the understanding of the sources of EC will be discussed below.

$C M B$ source apportionment of fine-particle elemental carbon. Estimating the EC contributions of all 11 source types could not be done directly using the CMB methodology owing to the lack of EC data in most of the profiles. Source sampling studies have not routinely incorporated $\mathrm{EC}$ measurements in the past. However, motor vehicle emissions have been extensively studied, and carbon emissions from motor vehicles have been well characterized (see references in Pierson and Brachaczek, 1983).

The amount of EC attributable to motor vehicles was determined using the estimated motor-vehiclederived $\mathrm{Pb}$. The composite motor vehicle source profile for fine-particle emissions was calculated using an approach similar to that used for Los Angeles (Cass and McRae, 1983). The 1983 summer average $P b$ content for gasoline in District 4 , which includes western Pennsylvania, was estimated to be $0.47 \mathrm{~g} \mathrm{~Pb} / \mathrm{gallon}$ of gasoline, based upon the $\mathrm{Pb}$ content of leaded gasoline in the area at the time (Shelton, 1984) and the national figures for the leaded fraction of gasoline consumed in August 1983 (44.8\%; Energy Information Administration, 1984). The composite motor vehicle fleet was determined to be a 6:1 gasoline to diesel ratio in terms of highway fuel consumption in western Pennsylvania during the summer of 1983 (U.S. Department of Transportation, 1983; National Petroleum News, 1984). Knowledge of the foregoing and use of appropriate fuel densities (Shelton, 1983, 1984) and airborne $\mathrm{Pb}$ and $\mathrm{EC}$ emission factors (Pierson and Brachaczek, 1976, 1983) resulted in a composite $\mathrm{EC}: \mathrm{Pb}$ ratio between $8: 1$ and $12: 1$ for the study period.

The observed fine $\mathrm{Pb}$ concentrations at Allegheny are compared in Fig. 2 with predicted fine $\mathrm{Pb}$ concen-

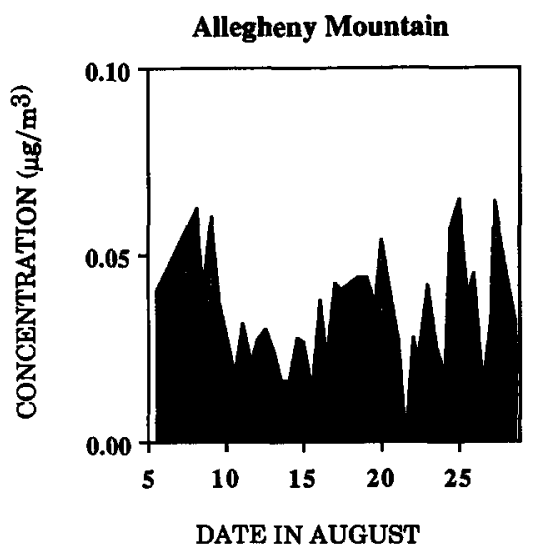

Fig. 2. CMB apportionment of fine-particle $\mathrm{Pb}$ at Allegheny Mountain. The area shown in gray is the estimated motorvehicle contribution. The area shown in black is the difference between the estimated motor-vehicle contribution and the observed fine $\mathrm{Pb}$, i.e. the fine $\mathrm{Pb}$ not attributed to motor vehicles. trations from motor vehicles. The $\mathrm{Pb}$ estimated to be from motor vehicles is shown as the lighter shaded area with the difference between the observed fine $\mathbf{P b}$ concentration and the predicted motor vehicle $\mathrm{Pb}$ shown in black. The black area thus represents the $\mathbf{P b}$ concentration not attributed to motor vehicles. Motor vehicles accounted for approximately $86 \pm 7 \%$ of the observed fine $\mathrm{Pb}$ at Allegheny. The incineration, iron-steel, copper plant, and oil sources contributed approximately $7 \%, 4 \%, 2 \%$ and $2 \%$, respectively, of the measured $\mathrm{Pb}$ at Allegheny, on the average. The motor-vehicle-derived EC concentration, based on the 8:1-12:1 EC:Pb source ratios above, would then be $0.34-0.49 \mu \mathrm{g} \mathrm{m}^{-3}$, or $28-41 \%$ of the measured EC at Allegheny Mountain. This range may represent a smaller portion of the EC than would be expected for the eastern U.S. Wolff et al. (1981) estimated that approximately $27 \%$ of the EC in Denver was emitted by motor vehicles, where wood burning was the largest contributor of EC at 39\%. Watson et al. (1990) also reported wood burning and motor vehicles as comparable and major sources of EC in Denver in the winter of 1987-1988. Wolff and Korsog (1985), using the APCA technique, estimated that about $47 \%$ of the measured EC in Detroit was from motor vehicles. There are few estimates of the motor vehicle contribution of EC measured in rural areas; therefore it is difficult to judge whether the CMB estimate is actually low for the Allegheny site.

An estimate was also made for the motor vehicle contribution to measured fine $\mathrm{Pb}$ and $\mathrm{EC}$ at Laurel Hill. Motor vehicles accounted for $87 \pm 7 \%$ of the measured $\mathrm{Pb}$ at Laurel Hill. The motor vehicle derived EC concentration would then be $0.27-0.46 \mu \mathrm{g} \mathrm{m}^{-3}$, or $20-34 \%$ of the measured EC at Laurel Hill. The absolute contributions of EC from motor vehicles at the two sites were quite similar, but the amount relative to the total EC observed was slightly lower at Laurel.

Comparison of PCA and CMB source apportionment results for elemental carbon

A comparison of the motor vehicle contributions to measured EC as determined by the PCA and CMB methods is shown in Table 6. While it is clear that agreement between sites for any one method is quite good, on the average the agreement between methods is much less so. However, the values in Table 6 indicate that the two methods do agree to within the estimated uncertainties. Two confounding factors have been mentioned previously as the probable sources of the uncertainty. In the PCA case, the commingling of the coal combustion and motor vehicle factors and the apparent split of EC between the soil component and the coal/motor vehicle component make definition of sources quite difficult. An additional indeterminate uncertainty is also imparted on the PCA solution because of the use of the varimax rotation in the apportionment (Henry, 1986; Low- 
Table 6. Motor vehicle contribution to measured elemental carbon. Units are $\mu \mathrm{g} \mathrm{m}^{-3}$

\begin{tabular}{lccr}
\hline Site & \multicolumn{2}{c}{ PCA method } & CMB method \\
\hline \multirow{3}{*}{ Pllegheny Mtn. } & $0.60 \pm 0.21^{*}$ & $0.81 \pm 0.23 *$ & $0.34 \pm 0.03-0.49 \pm 0.03$ \\
& $50 \% \pm 18 \%$ & $68 \% \pm 16 \%$ & $28 \pm 3 \%-41 \% \pm 3 \%$ \\
Laurel Hill & $0.56 \pm 0.18^{*}$ & $0.76 \pm 0.20^{*}$ & $0.27 \pm 0.03-0.47 \pm 0.03$ \\
& $41 \% \pm 14 \%$ & $56 \% \pm 11 \%$ & $20 \pm 3 \%-34 \pm 3 \%$ \\
\hline
\end{tabular}

* Uncertainty is calculated from the standard errors of the regression coefficients.

enthal and Rahn, 1987). In the CMB case, the lack of source signatures containing $\mathrm{EC}$ forces a surrogate tracer approach with $\mathrm{Pb}$ as the motor vehicle tracer. Since the $\mathrm{Pb} / \mathrm{EC}$ ratio is only poorly defined for the area vehicle emissions, considerable uncertainties are introduced into the calculations. There is one last uncertainty which could affect the comparison between PCA and CMB results in Table 6, and that is possible analytical errors in the determination of $\mathrm{EC}$ described in the Experimental section. If, in the limit, EC was overestimated by $25 \%$ in our analysis, it would have no effect on the PCA results, but it would lower the absolute contribution of any source to the observed EC by about $30 \%$. Correcting the observed concentrations, if appropriate, would raise the relative CMB motor vehicle contributions to $<52 \%$ at Allegheny Mountain and $<41 \%$ at Laurel Hill. Such a correction would bring the CMB and PCA results into quite good agreement at both sites.

\section{CONCLUSIONS}

The source apportionment of elemental carbon (EC) in the fine aerosol fraction found at two rural Pennsylvania sites in August 1983 has been carried out. Results calculated using principal component analysis and chemical mass balance techniques were found to agree to within the estimated uncertainties. While the two methods agree that the motor vehicle contribution is largest at both sites, the PCA approach gives consistently higher results on the average (about $60 \%$ by PCA vs $30-40 \%$ by CMB). According to the PCA analyses, other EC sources were oil combustion $(5 \%)$ and incineration (5\%). At Laurel Hill a smelter/industrial source $(10 \%)$ and an iron/steel source $(7 \%)$ were found to contribute.

Potential causes of uncertainty in the estimates by each approach were identified. In the PCA case, the tendency for sources to commingle on the same component made it impossible to define sources clearly, while in the case of CMB the lack of good carbon signatures for the various probable sources required that we use the $\mathrm{EC} / \mathrm{Pb}$ ratios to define the motor vehicle contribution. The latter presented additional problems because the motor vehicle $\mathrm{EC} / \mathrm{Pb}$ ratio was poorly defined. The CMB approach is also fairly sensitive to analytical uncertainties in the analysis of either the tracer species- $\mathbf{P b}$ in this case-or the EC analysis. For example, there is a significant area of uncertainty in the split of the total carbon between EC and organic carbon $(O C)$. In the event that some $O C$ is routinely counted as $\mathrm{EC}$, the $\mathrm{CMB}$. apportionment of EC will not be able to account for all the apparent EC; in fact, under such conditions the results will suggest that another EC source is important at the two sites. Nevertheless, the agreement between the two source apportionment techniques was quite good.

Acknowledgements - We are pleased to acknowledge the assistance of the Pennsylvania Turnpike Commission in providing access and electrical power to the two sites and helping us set up the experiment; we are especially indebted to Warren E. Kipp (deceased), Robert E. Davis, Nevin A. Miller, Carl Baker and the crew at the Allegheny Mountain Tunnel, and the Chief Engineer and Deputy Executive Director of the Pennsylvania Turnpike Commission, Robert H. Klucher. We are indebted to Karen M. Adams, James W. Butler, Ann C. Cleary, James C. Dziadosz, Larry P. Haack, Thomas J. Korniski, Fred E. McKelvy, William K. Okamoto, and Michael J. Rokosz, all of Ford, and Jeffrey M. Masters, formerly of the University of Michigan, for their participation in the field experiment. Also participating in the field experiment were E. Eugene Weaver (retired from Ford) and Adele Weaver. Finally, we thank Robert K. Stevens of EPA for providing the 10-micron inlets. Our work was supported in part by the National Science Foundation under Industry/University Cooperative Research Grant No. ATM8507282 to the University of Michigan.

\section{REFERENCES}

Andreae M. O., Andreae T. W., Ferek R. J. and Raemdonck H. (1984) Long-range transport of soot carbon in the marine atmosphere. Sci. total Envir. 36, 73-80.

Cass G. R., Conklin M. H., Shah J. J., Huntzicker J. J. and Macias E. S. (1984) Elemental carbon concentrations: estimation of a historical data base. Atmospheric Environment 18, 153-162.

Cass G. R. and McRae G. J. (1983) Source-receptor reconciliation of routine air monitoring data for trace metals: an emission inventory assisted approach. Envir. Sci. Technol. 17, 129-139.

Clarke A. D., Charlson R. J. and Radke L. F. (1984a) Airborne observations of Arctic aerosol-IV. Optical properties of Arctic haze. Geophys. Res. Lett. 11, 405-408.

Clarke A. D., Weiss R. E. and Charlson R. J. (1984b) Elemental carbon aerosols in the urban, rural, and remote marine troposphere and stratosphere: inferences from light 
absorption data and consequences regarding radiative transfer. Sci. total Envir. 36, 97-102.

Cooper J. A. and Watson J. G. (1980) Receptor oriented methods of air particulate source apportionment. J. Air Pollut. Control Ass. 30, 1116-1125.

Countess R. J. (1987) Interlaboratory round robin analysis of carbonaceous aerosol samples. Presented at the 3rd Int. Conf. Carbonaceous Particles in the Atmosphere, Lawrence Berkeley Laboratory, 5-8 October 1987.

Dzubay T. G. (1988) A composite receptor method applied to Philadelphia aerosol. Envir. Sci. Technol. 22, 126-144.

Energy Information Administration (1984) Monthly Energy Review, February 1984. Document DOE/EIA-0035(84.02), Dist. Category UC-98, Office of Energy Markets and End Use, U.S. Department of Energy, Washington, D.C., May 1984, p. 41.

Ferman M. A., Wolff G. T. and Kelly N. A. (1981) The nature and sources of haze in the Shenandoah Valley/Blue Ridge Mountains area. J. Air Pollut. Control Ass. 31, 1074-1082.

Fisher G. L., Chrisp C. E. and Hayes T. L. (1979) Carbonaceous particles in coal fly ash. In Proc. Conf. Carbonaceous Particles in the Atmosphere (edited by T. Novakov), pp. 229-232. LBL-9037, Lawrence Berkeley Laboratory, Berkeley, CA.

Friedlander S. K. (1973) Chemical element balances and identification of air pollutant sources. Envir. Sci. Technol. 7, 235-240.

Goldberg E. D. (1963) The oceans as a chemical system. In The Sea (edited by M. N. Hill), Vol. 2. Interscience, New York.

Gordon G. E. (1980) Receptor models. Envir. Sci. Technol. 14, 792-800.

Gordon G. E. (1986) Receptor modeling based on elemental analysis. In Chemistry of Multiphase Atmospheric Systems (edited by W. Jaeschke). NATO ASI Series, Vol. G6.

Gordon G. E. (1988) Receptor models. Envir. Sci. Technol. 22, 1132-1142.

Gordon G. E., Mizohata A., Han M. and Joseph J. (1989) Coal- and oil-fired power plant contributions to the atmosphere of the state of Maryland. Progress Report, University of Maryland, College Park.

Gray H. A., Cass G. R., Huntzicker J. J., Heyerdahl E. K. and Rau J. A. (1984) Elemental and organic carbon particle concentrations: a long-term perspective. Sci. total Envir. 36, $17-25$.

Groblicki P. J., Wolff G. T. and Countess R. J. (1981) Visibility reducing species in the Denver 'Brown Cloud'I. Relationships between extinction and chemical composition. Atmospheric Environment 15, 2473-2484.

Hammerle R. H. and Pierson W. R. (1975) Sources and elemental composition of aerosol in Pasadena, California by energy-dispersive X-ray fluorescence. Envir. Sci. Technol. 9, 1058-1068.

Harmon H. H. (1976) Modern Factor Analysis, 3rd edition. University of Chicago Press, Chicago, IL.

Harrison R. M. and Sturges W. T. (1983) The measurement and interpretation of $\mathrm{Br} / \mathrm{Pb}$ ratios in airborne particles. Atmospheric Environment 17, 311-328.

Henry R. C. (1986) Fundamental limitations of models using factor analysis. In Receptor Methods for Source Apportionment: Real World Issues and Applications (edited by T. G. Pace), pp. 68-77. Specialty Conference, Air Pollut. Control Assoc., Williamsburg, VA.

Henry R. C. and Hidy G. M. (1979) Multivariate analysis of particulate sulfate and other air quality variables by principal components, Part I, Annual data from Los Angeles and New York. Atmospheric Environment 13, 1581-1596.

Henry R. C. and Hidy G. M. (1982) Multivariate analysis of particulate sulfate and other air quality variables by principal components, Part II, Salt Lake City, Utah and St. Louis, Missouri. Atmospheric Environment 16, 929-943.
Henry R. C., Lewis C. W., Hopke P. K. and Williamson H. J. (1984) Review of receptor model fundamentals. Atmospheric Environment 18, 1507-1515.

Hopke P. K. (1985) Receptor Modeling in Environmental Chemistry. Wiley-Interscience, New York.

Hopke P. K. and Dattner S. L. (editors) (1985) Proceedings, Receptor Models Applied to Contemporary Pollution Problems. Air Pollution Control Association, Pittsburgh, PA.

Hopke P. K., Gladney E. S., Gordon G. E., Zoller W. H. and Jones A. G. (1976) The use of multivariate analysis to identify sources of selected elements in the Boston urban aerosol. Atmospheric Environment 10, 1015-1025.

Huntzicker J. J., Johnson R. L., Shah J. J. and Cary R. A. (1982) Analysis of organic and elemental carbon in ambient aerosols by a thermal-optical method. In Particulate Carbon: Atmospheric Life Cycle (edited by G. T. Wolff and R. L. Klimisch), pp. 79-88. Plenum, New York.

Japar S. M., Brachaczek W. W., Gorse R. A., Jr., Norbeck J. M. and Pierson W. R. (1986) The contribution of elemental carbon to the optical properties of rural atmospheric aerosols. Atmospheric Environment 20, 1281-1289.

Javitz H. S., Watson J. G. and Robinson N. (1988) Performance of the chemical mass balance model with simulated local-scale aerosols. Atmospheric Environment 22, 2309-2322.

Johnson R. L., Shah J. J., Cary R. A. and Huntzicker J. J. (1981) An automated thermal-optical method for the analysis of carbonaceous aerosol. In Atmospheric Aerosol: Source/Air Quality Relationships (edited by E. S. Macias and P. K. Hopke), pp. 223-233. ACS Symposium Series No. 167, American Chemical Society, Washington, D.C.

Keeler G. J. (1987) A hybrid approach for source apportionment of atmospheric pollutants in the Northeastern United States. Ph.D. dissertation, University of Michigan.

Keeier G. J., Brachaczek W. W., Gorse R. A., Jr., Japar S. M. and Pierson W. R. (1988) Effect of ambient humidity on dichotomous sampler coarse/fine ratios. Atmospheric Environment 22, 1715-1720.

Lowenthal D. H. and Rahn K. A. (1987) Application of the factor-analysis receptor model to simulated urban- and regional-scale data sets. Atmospheric Environment 21, $2005-2119$.

Macias E. S. and Hopke P. K. (editors) (1981) Atmospheric Aerosol: Source/Air Quality Relationships, ACS Symposium Series No. 167. American Chemical Society, Washington, D.C.

Miller S. S., Friedlander S. K. and Hidy G. M. (1972) A chemical element balance for the Pasadena aerosol. $J$. Colloid Interface Sci. 39, 165-178.

NAS (1980) Controlling Airborne Particles. Committee on Particulate Control Technology, National Academy of Sciences, Washington, D.C.

National Petroleum News (1984) National Petroleum News 1984 Factbook Issue, p. 90.

Olmez I., Sheffield A. E., Gordon G. E., Houck J. P., Pritchett L. C., Cooper J. A., Dzubay T. G. and Bennett R. L. (1988) Composition of particles from selected sources in Philadelphia for receptor modeling applications. J. Air Pollut. Control Ass. 38, 1392-1402.

Pace T. G. (editor) (1986) Transactions, Receptor Methods for Source Apportionment: Real World Issues and Applications. Transactions of an APCA International Specialty Conference, Williamsburg, VA, March 1985. Air Pollution Control Association, Pittsburgh, PA.

Pace T. G. and Watson J. G. (1987) Protocol for applying and validating the CMB model. Document EPA-450/4-87-010, U.S. Environmental Protection Agency, Research Triangle Park, NC.

Pierson W. R. and Brachaczek, W. W. (1976) Particulate matter associated with vehicles on the road. SAE Paper 760039; SAE Transactions 85, 209-227.

Pierson W. R. and Brachaczek W. W. (1983) Particulate 
matter associated with vehicles on the road-II. Aerosol Sci. Technol. 2, 1-40.

Pierson W. R., Brachaczek W. W., Gorse R. A., Jr., Japar S. M., Norbeck J. M. and Keeler G. J. (1987) Acid rain and atmospheric chemistry at Allegheny Mountain. Envir. Sci. Technol. 21, 679-691.

Pierson W. R., Brachaczek W. W., Gorse R. A., Jr., Japar S. M., Norbeck J. M. and Keeler G. J. (1989) Atmospheric acidity measurements on Allegheny Mountain and the origins of ambient acidity in the northeastern United States. Atmospheric Environment 23, 431-459.

Pierson W. R. and Russell P. A. (1979) Aerosol carbon in the Denver area in November 1973. Atmospheric Environment 13, 1623-1628.

Pratsinis S. E., Novakov T., Ellis E. C. and Friedlander S. K. (1984) The carbon containing component of the Los Angeles aerosol: source apportionment and contributions to the visibility budget. J. Air Pollut. Control Ass. 34, 643-650.

Prastinis S. E., Zeldin M. D. and Ellis E. C. (1988) Source resolution of the fine carbonaceous aerosol by principal component-stepwise regression analysis. Envir. Sci. Technol. 22, 212-216.

Rahn K. A. and Lowenthal D. H. (1985) Pollution aerosol in the northeast: northeastern-midwestern contributions. Science 228, 275-284.

Rahn K. A. and McCaffrey R. J. (1980) On the origin and transport of the winter arctic aerosol. Ann. N.Y. Acad.Sci. 338, 145-173.

Sexton K., Liu K. S., Hayward S. B. and Spengler J. D. (1985) Characterization and source apportionment of wintertime aerosol in a wood-burning community. Atmospheric Environment 8, 1225-1236.

Sheffield A. E. and Gordon G. E. (1986) Variability of particle composition from ubiquitous sources: Results from a new source-composition library. In Receptor Methods for Source Apportionment: Real World Issues and Applications (edited by T. G. Pace), pp. 9-22. Specialty Conference, Air Pollut. Control Assoc., Williamsburg, VA.

Shelton E. M. (1983) Diesel fuel oils, 1983. NIPER-132 PPS, National Institute for Petroleum and Energy Research, Bartlesville, OK, November 1983.

Shelton E. M. (1984) Motor gasolines, summer 1983. NIPER-133 PPS, National Institute for Petroleum and Energy Research, Bartlesville, OK, February 1984.

Spengler J. D. and Thurston G. D. (1984) Mass and elemental composition of fine and coarse particles in six U.S. cities. $J$. Air Pollut. Control. Ass. 34, 1162-1171.

Stevens R. K., Dzubay T. G., Lewis C. W. and Shaw R. W., Jr. (1984) Source apportionment methods applied to the determination of the origin of ambient aerosols that affect visibility in forested areas. Atmospheric Environment 18, 261-272.

Stevens R. K. and Pace T. G. (1984) Overview of the mathematical and empirical receptor models workshop (Quail Roost II). Atmospheric Environment 18, 1499-1506.

Stokes R. H. and Robinson R. A. (1948) Standard solutions for humidity control at $25^{\circ} \mathrm{C}$. Indust. Eng. Chem. 41, 2013.

Thurston G. D. (1983) A source apportionment of particulate air pollution in metropolitan Boston. Ph.D. dissertation Harvard School of Public Health, Boston, MA.
Thurston G. D. and Laird N. M. (1984) Tracing aerosol pollution. Science 227, 1406-1407.

Thurston G. D. and Spengler J. D. (1985a) A quantitative assessment of source contributions to inhalable particulate matter pollution in Metropolitan Boston. Atmospheric Environment 19, 19-25.

Thurston G. D. and Spengler J. D. (1985b) A multivariate assessment of meteorological influence on inhalable particle source impacts. J. clim. appl. Met. 24, 1245-1256.

Tuncel S. G. (1986) Regional scale receptor modeling in the Northeast U.S. Ph.D. dissertation, University of Maryland, College Park, MD.

U.S. Department of Transportation (1983) Highway Statistics 1983. U.S. Government Printing Office, Washington, D.C., pp. $8,9$.

Vossler T. L., Lewis C. W., Stevens R. K. Dzubay T. G., Gordon G. E., Tuncel S. G., Russwurm G. M. and Keeler G. J. (1989) Composition and origin of summertime air pollutants at Deep Creek Lake, Maryland. Atmospheric Environment 23, 1535-1547.

Watson J. G. (1981) Receptor Models Relating Ambient Suspended Particulate Matter to Sources. Document EPA600/2-81-039, U.S. Environmental Protection Agency, Research Triangle Park, NC.

Watson J. G. (editor) (1989) Transactions, Receptor Models in Air Resources Management. Transactions of an APCA International Specialty Conference, San Francisco, CA, February, 1988. Air \& Waste Management Association, Pittsburgh, PA. See also Watson J. G., Chow J. C. and Mathai C. V. (1989) Receptor models in air resources management: a summary of the APCA International Specialty Conference. J. Air Waste Management Assoc. $(J A P C A)$ 39, 419-426.

Watson J. G., Cooper J. A. and Huntzicker J. J. (1984) The effective variance weighting for least squares calculations applied to the mass balance receptor model. Atmospheric Environment 18, 1347-1355.

Watson J. G., Chow J. C., Pritchett L. C., Houck J. A., Ragazzi R. A. and Burns S. (1990) Chemical source profiles for particulate motor vehicle exhaust under cold and high altitude operating conditions. Sci. total Envir. 93, 183-190.

Wolff G. T., Countess R. J., Groblicki P. J., Ferman M. A., Cadle S. H. and Muhlbaeir J. (1981) Visibility-reducing species in the Denver Brown Cloud. Atmospheric Environment 15, 2485-2502.

Wolff G. T., Ferman M. A., Kelly N. A., Stroup D. P. and Ruthkosky M. S. (1982) The relationships between the chemical composition of the fine particles and visibility in the Detroit metropolitan area. J. Air Pollut. Control Ass. 32, 1216-1220.

Wolff G. T. and Korsog P. E. (1985) Estimates of the contributions of sources to inhalable particulate concentrations in Detroit. Atmospheric Environment 19, $1399-1409$.

Wolff G. T., Morrissey M. L. and Kelly N. A. (1984) An investigation of the sources of summertime haze in the Blue Ridge Mountains using multivariate statistical methods. J. clim. appl. Met. 23, 1333-1341.

Wolff G. T., Stroup C. M. and Stroup D. P. (1983) The coefficient of haze as a measure of particulate elemental carbon. J. Air Pollut. Control Ass. 33, 746-750. 